\title{
A multimodalidade da revisão de texto: um caminho para o letramento
}

\author{
Harrison da Rocha \\ Rafael Mingote ${ }^{2}$
}

\section{Resumo}

A linguagem escrita está se tornando, cada vez mais, apenas um dos muitos modos de representação do domínio público. A Análise de Discurso Crítica constitui-se a partir da percepção do discurso como um elemento das práticas sociais em uma perspectiva dialética entre linguagem e sociedade. Assim, essa teoria considera o discurso como uma integração de diversas formas de modos semióticos, em que os falantes e as falantes, ao fazerem uso das linguagens disponíveis, agem sobre as outras pessoas e sobre o mundo. De outra parte, a comunicação sempre foi multissemiótica, mas assumir essa perspectiva torna-se algo novo e assustador, principalmente para as sociedades grafocêntricas. As mudanças no cenário comunicacional têm ficado fora do ensino de Língua Portuguesa no Brasil porque, em grande parte, valoriza-se, ainda, o modelo autônomo do Letramento, centrando-se no entendimento da nomenclatura gramatical em atividades fossilizadas, não significativas e fora do contexto social dos alunos e alunas. Nossa perspectiva nesta pesquisa se justifica porque devemos acompanhar as mudanças hodiernas e preparar os futuros docentes para as atividades de linguagem mais amplas, trazendo as práticas sociais, os eventos discursivos e as práticas de texto para sala de aula. Esta prática de texto pode ser aplicada pela Revisão de Texto. Nosso projeto tem como fundamentação teórica Barton,(1994) Hamilton \& Ivanic (2000), Street (1993), Fairclough (2003); Chouliaraki \& Fairclough (1999), Kress e Van Leeuwen (1996).

Palavras-chave: Ensino de língua portuguesa. Revisão de texto. Análise de discurso crítica. Letramento.

1 Professor do UniCEUB; mestre e doutorando em Linguística pela Universidade de Brasília (UnB); especialista em Língua Portuguesa pela UnB; Coordenador dos Cursos de Pós-graduação em Língua Portuguesa; atualmente, desenvolve pesquisa em Análise de Discurso Crítica, Multimodalidade, Letramento e Revisão de Texto; autor de artigos científicos e de livros nestas áreas; rocha123@gmail.com.

2 Professor da rede privada de ensino do Distrito Federal, Graduado pelo UniCEUB em Letras, Português/Inglês e suas respectivas literaturas. 


\section{Introdução}

Termos sido alunos de disciplinas como a Análise de Discurso e Letramento no curso de Letras, ${ }^{3}$ permitiu-nos entender que a mudança do ensino de Língua Portuguesa (LP) era necessária e, acima de tudo, urgente, pois o Letramento que as escolas praticam é ainda autônomo, sem nenhuma conexão com o social e com a vida dos alunos. Então, após algumas leituras de cunho crítico, achamos conveniente tratar desse assunto e pesquisá-lo, tendo como base os pressupostos teóricos da Análise de Discurso Crítica (ADC), em interface com a Semiótica Social, a Multimodalidade e o Letramento.

Nosso objeto de estudo é o ensino de Língua Portuguesa e sua abordagem autônoma calcada na Gramática Tradicional (GT). Nosso objetivo geral é repensar esta prática à luz das teorias críticas, notadamente a ADC e o Letramento. Para tanto nos propomos responder às seguintes questões de pesquisa:

I. As escolas estão cumprindo o papel de ensinar Língua Portuguesa por meio de gêneros?

II. Qual a importância das teorias críticas associadas à Revisão de Texto?

III.Como pode a revisão de texto, sob uma perspectiva Multimodal, ser associada às teorias críticas e incentivar uma nova forma de Letramento?

A metodologia escolhida para responder a essas questões é baseada em Flick (2004) e é de cunho qualitativo, pois se trata da observação de fatos sociais e sempre permitem mais de uma interpretação. Esse tipo de pesquisa é importante neste caso, pois não visa saber a quantidade de opiniões a respeito de um determinado assunto ou quantificar atitudes e assim uniformizá-las, mas, sim, analisar fatos socioculturais que integram o grupo pesquisado nas relações com o meio e com o mundo.

Este trabalho é o resultado da pesquisa desenvolvida no âmbito do $6^{\circ}$ Programa de Iniciação Científica (PIC) do UniCEUB, tendo como orientador o professor Harrison da Rocha. 
A pesquisa qualitativa tenta, ao máximo, interagir e analisar práticas de relacionamento entre mundo e indivíduo, possibilitando, assim, um resultado mais rico e cheio de possibilidades. Assim, foi do nosso interesse observar comportamentos na área educacional, analisar materiais de apoio, assim como entender como funciona o processo de ensino-aprendizagem de LP no contexto pesquisado.

O corpus utilizado para a consecução da pesquisa está constituído de gêneros discursivos, cuja finalidade será evidenciar como esta prática, dentro da sua complexidade, pode ser associada a uma atividade que valoriza a análise global do texto, a Revisão de Texto, e com isso poder ser aplicado ao ensino de LP como um caminho não apenas para o Letramento formal, mas também para os Multiletramentos.

As bases teóricas e as categorias analíticas são da Análise de Discurso Crítica (ADC). Nesta área, valorizamos microestruturas - Léxico, elementos coesivos, estruturas sintáticas, tempos e modos verbais etc.; na prática discursiva, analisamos a natureza do gênero propaganda e sua produção, distribuição e consumo; na prática social, evidenciaremos a ideologia presente no gênero propaganda. Para complementar, fizemos a análise da imagem visual - personagens, cores, posicionamento.

\section{0 ensino da língua portuguesa: uma prática monomodal ${ }^{4}$}

As críticas ao ensino tradicional de Língua Portuguesa não são recentes. O que ensinar então para as pessoas que utilizam competentemente sua língua materna? Devemos priorizar a norma padrão? Devemos nos ater à modalidade escrita? Ou ensinar os diferentes usos e funções da linguagem?

Antes de precisarmos "o que ensinar" e "como ensinar", é preciso que resgatemos nossas concepções de linguagem e de ensino de língua, que o professor deve

\footnotetext{
4 Por prática monomodal entende-se a atividade de ensino de língua em sala de aula prestando atenção apenas à escrita, não se levando em consideração a construção multissemiótica do gênero.
} 
ter. Essas são vitais para a configuração do processo ensino-aprendizagem, pois definem não só a prática pedagógica bem como as metodologias adotadas.

Uma diferente concepção de linguagem constrói não só uma nova metodologia, mas principalmente um novo conteúdo de ensino. A língua nada mais é que um fator social e sofre mudanças continuamente, por isso não deve ter o mesmo tratamento que teve outrora. Um passo importante a ser dado quando se trata de questões da língua, em especial o ensino de LP, é ter plena consciência de que a GT não pode ser tomada como verdade absoluta. Uma gramática que privilegia apenas uma variante, focada apenas na linguagem padrão (escrita), considerando a escrita como espelho da fala e tratando as demais como "um problema", precisa ser revista. Esse repensar se torna prioridade para que aconteçam as tão desejadas mudanças na concepção de ensino de LP nas escolas brasileiras.

Após conhecermos mais de perto as necessidades e interesses da escola, dos professores, das famílias e dos alunos, gostaria de traçar em linhas gerais um ensino de língua que acredito ser mais coerente e significativo.

Sabe-se que a língua é heterogênea, variável, instável e está sempre em constante mudança. A língua é uma atividade social que compreende todos os seus falantes, seja pela fala, seja pela escrita ou outra forma de linguagem. Mas o que dizer então da GT que, apesar das mudanças correntes na língua, continua a mesma? Outro aspecto que acreditamos ser pertinente citar são as questões que envolvem a globalização e a pós-modernidade. Sabemos que a exigência e os valores atribuídos à escrita mudaram consideravelmente com a chegada da TV, do rádio e, principalmente, da Internet. ${ }^{55}$ Assim é importante que o ensino seja repensado principalmente dentro do âmbito escolar. Esses são alguns fatos que levam especialistas da linguagem a criticarem a GT.

\footnotetext{
5 A Pós-Modernidade é caracterizada, dentre outros fatores, pelas transformações tecnológicas que mudaram sobremaneira as formas de interação, influenciando, assim, uma remodelagem na produção de gêneros. Não apenas isso, mas também possibilitaram a criação de novos gêneros: blogs, fotologs etc.
} 
Observa-se nos próprios livros didáticos uma nova preocupação com o linguístico e com o visual, mas, muitas vezes, nesse contexto, essas imagens aparecem como mera ilustração.

Ao perceber determinadas falácias, o estudante inquire o professor para explicar essas afirmações. Às vezes, o professor é tão radical quanto o gramático, e não aceita a participação do discente, pois também não domina a GT. Essa postura do docente compromete o rendimento da aprendizagem, deixando sequelas educacionais no aluno a ponto de se incompatibilizar com a matéria e também com o professor. Assim, transmite-se essa visão distorcida sobre o ensino da língua como sendo o "decoreba" de uma infinidade de regras e de exceções, complicando mais a vida do aluno, principalmente daquele oriundo de camada social menos privilegiada.

Quase sempre, o que se vê dentro de sala de aula é o conflito entre grupos etários e étnicos e, sobremaneira, entre classes sociais. Podemos entender que a gramática tem sido o instrumento de preconceito entre linguagem e grupos sociais, e os professores não têm cumprido o papel de ensiná-la com eficácia. Em consequência, estão sendo transmitidos aos alunos do Ensino Fundamental e em especial do Ensino Médio, conceitos linguísticos falhos.

Refletindo sobre esse ensino posto em prática pelas escolas públicas e particulares, verifica-se uma atitude lastimável que é "encher a cabeça" do estudante com algo confuso, incompleto. O conhecimento teórico não contribui significativamente para o domínio da língua. Geraldi (1996, p. 21) afirma que "O ensino da língua foi desviado para o ensino da teoria gramatical".

Isso é o resultado de um ensino centrado na GT. O conhecimento se esvai por falta de sustentação científica; é como caminhar por sobre o lodo, não há firmeza nos passos dados, e a queda é inevitável.

Assim, respondemos a primeira questão de pesquisa. Na próxima seção, serão apresentadas as teorias que possibilitaram rever o ensino de LP em uma perspectiva crítica: a Análise de Discurso Crítica (ADC), a Semiótica Social, a Multimodalidade, o Letramento e a Ideologia. 


\section{Embasamento teórico}

Nesta Seção, traremos à baila as teorias que nos servem de base para a consecução desta pesquisa: a Análise de Discurso Crítica (ADC) na figura de Norman Fairclough (2001); Semiótica Social (HODGE; KRESS, 1988); Multimodalidade (KRESS; VAN LEEUWEN, 1996, 2001), Letramento (KLEIMAN, 1995; MARCUSCHI, 2002; STREET, 1984; BARTON, 1994; HAMILTON, 1998.

\subsection{A análise do discurso crítica (ADC)}

O que faz especificamente uma prática discursiva ser discursiva? De acordo com Fairclough (2001), parte da resposta está na linguagem como materialização no texto, a outra parte está na prática social, com todas as suas implicações ideológicas e políticas. $\mathrm{O}$ evento discursivo engloba tudo isso, pois é um produto histórico - ambiente econômico, político e institucional (origem do discurso). Desse modo, devem-se levar em consideração a produção, a distribuição e o consumo de textos. O primeiro diz respeito a como os textos são produzidos de maneira particular em contextos sociais específicos; o segundo refere-se ao consumo de textos em contextos sociais diversos, variando de acordo com sua natureza; o último explica como os textos são consumidos no mundo, podendo ser distribuídos de forma simples (conversação casual), ou complexa - o texto jornalístico construindo leitores múltiplos, por exemplo.

Outro aspecto importante na obra de Fairclough (2001) é a concepção tridimensional do discurso. Veja-se o quadro: 
Quadro tridimensional do discurso ${ }^{6}$

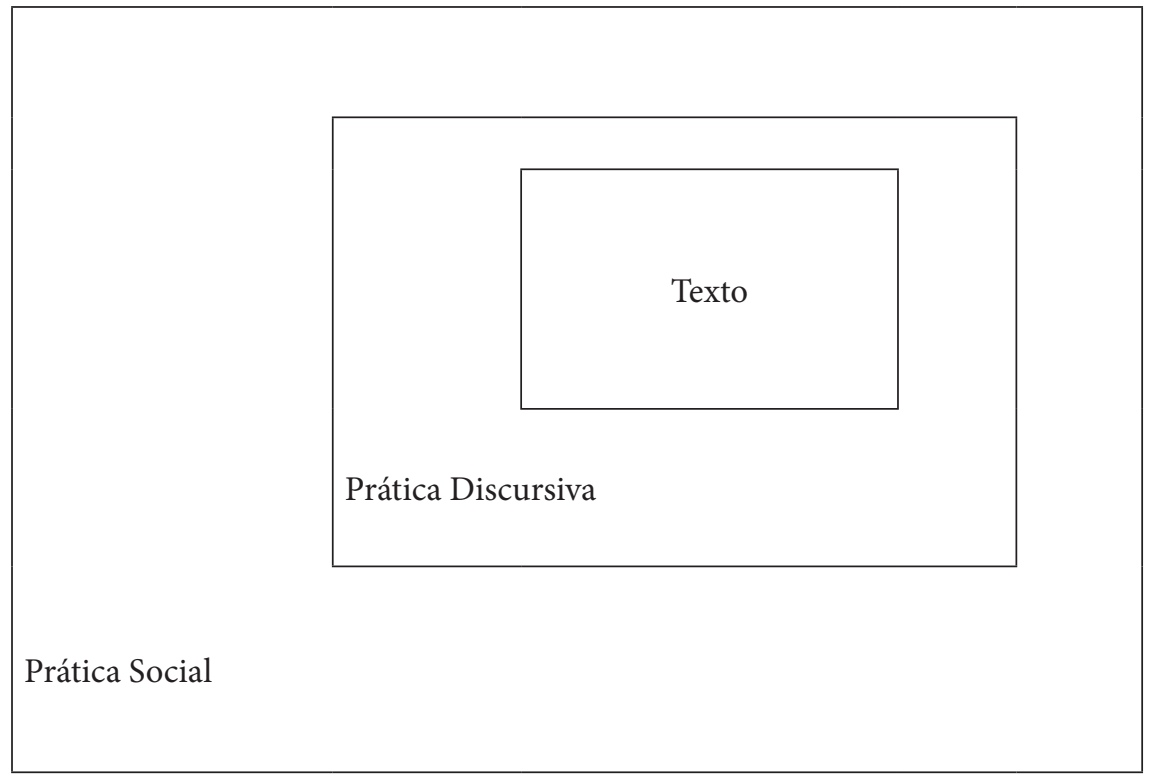

Ao apresentar tal esquema, o autor objetiva reunir três tradições analíticas que são indispensáveis para quem quiser fazer análise de discurso: a tradição da análise textual - detalhada na Linguística (ADC); a tradição macrossociológica de análise da prática social em relação às estruturas sociais; e a tradição interpretativa (microssociológica) de considerar a prática social como alguma coisa que as pessoas produzem ativamente e entendem com base em procedimentos de senso comum partilhado. A parte que trata da análise é denominada descrição; as partes que tratam da análise da prática discursiva e da análise da prática social da qual o discurso faz parte são denominadas de interpretação.

A produção e a interpretação de texto são processos de níveis: processo inferior - análise das sequências de sons ou marcas gráficas em frases; processo superior - diz respeito ao sentido, à atribuição de sentidos às frases, a textos completos e a partes ou "episódios" de um texto que consistem de frases que podem ser analisadas coerentemente conectadas. Além disso, têm de ser levados em consideração outros elementos como o fator de redução de ambivalência: contexto de situ-

${ }^{6}$ Este quadro será associado à prática da Revisão de Texto. 
ação, prática social etc.; a força dos enunciados que está ligada a seu componente acional, parte do seu sentido interpessoal, na ação social que realiza, que ato de fala realiza - dar ordens, perguntar, ameaçar, prometer etc. Nesse caso, antes que se passe a analisar o contexto de situação, ou mesmo o contexto sequencial, para analisar a força do enunciado, deve-se chegar a uma interpretação sobre qual é o contexto, o que envolve pistas e recursos dos membros - mapa mental de ordem social: identidade social (etnia, idade, gênero).

A coerência é propriedade de interpretação. Um texto é considerado coerente quando faz sentido para o receptor, mesmo que não haja operadores lógicos. Ao fazer-se interpretação textual, sujeita-se ao texto. E, por último, intertextualidade que, segundo o autor, é de maior importância para ADC, pois é a propriedade que têm os textos de serem cheios de fragmentos de outros. Pode ser delimitada explicitamente (intertextualidade manifesta - ocorrência explícita de outro(s) texto(s), ou implicitamente (intertextualidade constitutiva - ou interdiscursividade - constituição heterogênea de texto por meio de elementos das ordens do discurso (interdiscursividade).

Fairclough ainda afirma que, quando se faz uma análise de texto, relaciona-se este com a função ideacional da linguagem e com os sentidos ideacionais - ou com a "construção da realidade social". Em 2003, ele sustenta que os traços fonológicos, vocabulário e metáfora (advérbios intensificadores), jogo entre linguagem verbal e corporal são elementos identificadores da identidade.

Os tópicos analíticos levantados pelo autor em 2001 são: conectivos e argumentação, transitividade e tema, significação das palavras, criação de palavras, metáfora e análise. Paralelamente aos aspectos de sua teoria, apresentamos o aprofundamento para a análise de texto da obra de 2003: a) significação das palavras - os significados das palavras e a lexicalização de significados são questões que são variáveis socialmente contestadas e facetas de processos sociais e culturais mais amplos; b) relações gramaticais e semânticas - dão-nos a relação entre características linguísticas e gêneros discursivos e, em suas práticas sociais, o que as pessoas fazem com esses gêneros; c) transitividade e tema - podem ser divididos em dois principais processos: os relacionais - em que o verbo marca uma relação (ser, 
tornar-se) entre os participantes, e de ação, em que um agente age em direção a um objetivo. O tema, por sua vez, significa uma dimensão textual da gramática da oração dedicada aos modos pelos quais os elementos da oração são posicionados de acordo com sua proeminência informacional. Rema é a parte final.

As bases teóricas e as categorias analíticas são oriundas da Análise de Discurso Crítica (ADC), pois nos permitem um leque muito maior de possibilidades teórica e analítica. A ADC nos possibilita trabalhar com a interdisciplinaridade, uma vez que lida com questões bastante amplas - Linguagem, Sociedade e Poder. Essa tríade deve ser ampliada, uma vez que as representações sociais manifestam-se em elementos semióticos vários - estruturas linguísticas, sons, imagens, cores. Desse modo devemos ampliar o escopo da ADC com a Semiótica Social, Multimodalidade e Letramento. Essas teorias nos serão importantes nas questões do Letramento.

\subsection{Semiótica social}

Kress, Leite-Garcia e Van Leeuwen (2000), no artigo "Semiótica Discursiva”, partem da premissa de que o interesse do produtor de um signo conduz a uma relação motivada entre significado e significante. Segundo esse ponto de vista, a defesa de um signo imotivado por Saussure é deixada para trás. Na nova perspectiva, além da motivação do signo, é também considerada a ideologia, que se torna componente indissociável do signo linguístico. Essa mudança conceitual contradiz frontalmente a Semiótica ortodoxa, que tem uma abordagem descritiva, esvaziada de motivação ideológica.

Nesse ponto, ao incorporarem a imagem aos estudos linguísticos, os semioticistas sociais diferem dos analistas de discurso, pois as representações visuais não são imunes nem alheias à ideologia, abrindo-se plenamente a interpretações ideológicas. Por essa razão, os semioticistas críticos enfatizam a estruturação sistemática da imagem em uma sintaxe visual, distanciando-se, desse modo, de grande parte dos trabalhos até aqui realizados no trabalho linguístico, cuja abrangência não transcende o nível do vocabulário, da frase. Em suma, com essa mudança de enfoque, surge 
nova perspectiva para o estudo discurso que, agora, envolve o iconográfico. Nosso próximo passo teórico será a Multimodalidade, de base na Semiótica social.

\subsection{A multimodalidade}

O visual tornou-se termo corriqueiro nos currículos de informação tecnológica, para traduzir a nova onda de representação visual de informação que anteriormente era codificada apenas pela linguagem (escrita ou oral). Se essas não são mais as modalidades semióticas centrais, então as teorias da linguagem podem explicar apenas parte do panorama comunicacional.

Em Multimodal discourse: the modes and media contemporary communication, Kress e Van Leeuwen (2001) objetivam descrever como as fontes da Multimodalidade permitem a realização do sentido de muitas maneiras e em diferentes níveis. Eles defendem que a linguagem multimodal pode significar em múltiplas articulações. Esses modos semióticos contam com uma multiplicidade de outros que significam à medida que eles contribuem para uma multiplicidade de níveis (strata) de articulações. Os exemplos de modos que eles descrevem no livro incluem linguagem, narrativa, modalidade escrita, gesto, arranjo espacial, imagens, cor, layout, só par citar alguns. Desse modo, abandonaram a ideia de que os diferentes modos semióticos nos textos multimodais têm tarefa predefinida e emoldurada.

Os autores defendem um enfoque multimodal para compreender todos os modos empregados por um grupo cultural, incluindo a língua escrita e a oral, uma vez que, em geral, a Análise de Discurso (AD e a ADC) concentraram-se no texto linguisticamente realizado. Segundo eles, o enfoque multimodal é uma saída de análise mais justa, pois tenta compreender todos os modos de representação social que entram nos modos com a mesma precisão metodológica que a $\mathrm{AD}$ ou a $\mathrm{ADC}$ são capazes de lançar no texto. Assim, o interesse não está na análise semiótica convencional, mas nas origens sociais e na produção dos modos e na sua recepção.

Os autores traçam os quatro domínios da prática na qual os sentidos são predominantemente realizados. No entanto, eles não veem essas camadas como 
sendo ordenadas hierarquicamente, como uma após outra. As quatro camadas são: a) discurso: são conhecimentos socialmente construídos (algum conhecimento) da realidade; b) design: maneiras de realizar discursos em contextos determinados; c) produção: é a articulação na forma material dos produtos; d) distribuição: reprodução dos produtos e dos eventos semióticos.

Em Kress, Leite-Garcia e Van Leeuwen (2000), a análise semiótico-social do texto multimodal parte de alguns pressupostos, que caracterizam os textos multimodais da seguinte forma: a) um conjunto de modos semióticos está sempre presente em toda produção ou leitura dos modos; b) cada modalidade tem suas potencialidades específicas de representação e de comunicação produzidas culturalmente, mas inerentes a cada modo; c) é preciso compreender a maneira de ler essas produções como coerentes em si mesmas; d) tanto os produtores quanto os receptores têm poder em relação aos modos semióticos; e) escritores e leitores produzem signos complexos que emergem do "interesse" do produtor; f) o "interesse" determina a convergência de um complexo conjunto de fatores: histórias sociais e culturais, contextos sociais atuais; g) o interesse em representações aptas em uma comunicação efetiva significa que os produtores de signos elegem significantes (formas) apropriados para expressar sentidos, de maneira que a relação entre um e outro não resulte arbitrária, mas motivada.

Como se pôde observar nesta subseção, o discurso multimodal ocupa um espaço cada vez mais representativo nas práticas sociais contemporâneas. Nessa perspectiva, é impossível interpretar os modos prestando atenção somente na língua escrita, pois um texto multimodal deve ser lido em conjunção com todos os modos semióticos dessa produção. Essa afirmação pode realmente fazer a diferença ao se estudar linguagem em sala de aula.

\subsection{0 letramento}

Desde a Antiguidade Clássica, a linguagem escrita sempre teve privilégio social e histórico. Esse grafocentrismo provocou o distanciamento entre a fala e a escrita e implicou estudo de linguagem em termos da dicotomia oral/escrito. No 
Estruturalismo, houve uma inversão de valores: apenas à modalidade oral era atribuído o status de língua (VIEIRA, 2003).

As restrições a esse modelo dicotômico, ainda segundo Vieira (2003), provocaram o surgimento de novos estudos - intitulados de Letramento. Desse modo, houve mudanças significativas no modo de encarar as práticas de escrita, opondo-se aos estudos da Linguística Descritiva que considera a escrita apenas como ferramenta ou mero instrumento. Barton (1994) menciona tipos diferentes de letramentos, que, de algum modo, ajudam o indivíduo a interagir com outros membros da coletividade.

Tal dicotomia foi substituída, na década de 1980, pela noção de continuum (CHAFE, 1982). Naquela década, a tese do continuum logrou êxito, uma vez que ocorreu a superposição do oral e do escrito, porém Street (1993) critica essa abordagem, tratando-a como inadequada para o problema, pois, segundo ele, a diferença entre o oral e o escrito só poderá ser compreendida plenamente à luz do contexto social.

Apesar da controvérsia do termo "letramento", Kleiman (1995) afirma que o Letramento é mais bem compreendido como um conjunto de práticas sociais, coincidindo com Marcuschi (2002). Ela sustenta, ainda, que o termo "letramento" é usado em vez de "alfabetização" por causa de, em certos grupos sociais, as crianças serem letradas por possuírem estratégias orais letradas, antes mesmo de serem alfabetizadas.

A respeito do Letramento, já se sabe que é caracterizado assim: lida necessariamente com texto e discurso, podendo associar outras formas semióticas (um dos motes para o nosso trabalho). Está associado a diferentes domínios sociais; é historicamente situado; é constituído por meio de práticas sociais e de eventos de Letramento; se as práticas de Letramento mudarem, novas serão frequentemente construídas por meio de processos informais de aprendizagem e de produção de sentidos; destaca-se explicitamente o fato de que todas as práticas são aspectos, não apenas da cultura, mas também das estruturas de poder em uma sociedade; há diferentes letramentos associados a diferentes domínios da vida (inclui-se aqui o 
aspecto visual); o Letramento extrapola o mundo da escrita tal qual ele é concebido pelas instituições que se encarregam de introduzir formalmente os sujeitos nesse mundo.

Hamilton et al. (1998) retomam a primeira característica do Letramento no parágrafo anterior, ampliam as noções de Letramento e discutem, também, o papel de dados visuais na pesquisa social. Em particular, informações que podem ser oriundas de imagens da mídia. O principal ponto dos autores a ser estudado é mostrar que as práticas de Letramento não estão presas somente a eventos de ações situadas, mas a momentos de práticas capturadas pela fotografia. Para Hamilton, as fotografias são particularmente apropriadas para documentação de aspectos do Letramento desde que estejam associadas a textos.

Todas essas teorias nos ajudam a permear um campo muito mais amplo de trabalho que envolve modos semióticos diversos. Associar a Revisão de Texto a uma prática multimodal e ver como ela pode ser aplicada ao ensino de LP é o nosso caminho a percorrer de agora em diante. Mas para chegarmos ao nosso objetivo, é necessário avaliar como se dá essa Revisão de Texto na atualidade e como ela se relaciona com essas teorias críticas, foco da próxima seção.

\section{A revisão de texto: uma prática multimodal}

O aluno, ao chegar à escola, traz a marca de uma sociedade que o discrimina linguisticamente; torna-se fruto de uma prática desmotivadora. $\mathrm{O}$ aprendiz tem de decorar regras de uma língua tão distante de seu dia a dia, ver o que já sabe, porque a instituição e o professor não fazem um levantamento sensato da real necessidade dele. O que aprende não tem ressonância com seu contexto social. Além disso, só a voz do professor é ouvida; sua leitura de texto e, por consequência, de mundo, é a única autorizada, alijando a natureza primeira da linguagem, que é o dialogismo.

Kleiman (1995), ao falar sobre práticas desmotivadoras em sala de aula, diz que ninguém gosta de fazer aquilo que não tem sentido; segundo ela, as práticas escolares estão baseadas no entendimento limitado e incoerente do que seja ensi- 
nar Língua Portuguesa, estão calcadas em concepções erradas sobre a natureza do texto e da leitura, e o pior: sobre a própria linguagem, e sobre o letramento.

A mesma autora crê que as deficiências do sistema educacional na formação de sujeitos plenamente letrados não decorrem apenas do fato de o professor não ser um representante pleno da cultura letrada nem das falhas num currículo que não instrumentaliza o professor para o ensino. Ela acredita que as falhas são mais profundas, pois são decorrentes dos próprios pressupostos que subjazem ao modelo de Letramento escolar.

Por isso, a introdução da Revisão de Texto como prática multimodal nas aulas de Língua Portuguesa, como aprendizado global e como prática de relevância social, justifica-se por vários fatores: pode contribuir para um ensino melhor e ajudar a tornar o aluno mais letrado na prática e em muitas instâncias semióticas; e nossa pesquisa pode contribuir para a abertura de mais uma área de estudo.

A partir dessas definições, fazem-se necessários estudos que avaliem e discutam com mais afinco os vários e possíveis modos semióticos existentes na língua. É fundamental uma reflexão que possibilite um olhar mais crítico, não se esquecendo de buscar soluções, propostas mais coerentes e eficazes, com o intuito de renovar o ensino de gramática, que há muito tem deixado a desejar.

O que tem a ver a Revisão de Texto com as teorias críticas? Vejamos um pouco sobre a natureza da Revisão de Texto. Ela tem sido mal empregada e nunca foi associada a uma teoria formal que lhe desse lastro para sua existência. É voz quase unânime que ela é usada apenas para adequar o texto à norma-padrão, mas isso perpetua o preconceito contra as outras variedades de língua. $\mathrm{Na}$ verdade, sabemos que ela é muito mais que isso e que é um foro ideal para se letrar. Nossa abordagem a vê como uma atividade crítica em que há negociação de sentido e como um método que trabalha com questões de linguagem bem mais amplas. Antes de nos aprofundarmos nesta questão, vejamos a natureza da Revisão de Texto.

O que tem que ver a Revisão de Texto com a teoria da Multimodalidade? A própria atividade de revisão já é uma prática multissemiótica. Não há um gênero 
a ser revisado que não tenha o hibridismo: emprego de família de letras, uma formatação, a estrutura prototípica do gênero, um determinado tipo de papel. Todos esses elementos são significativos, uma vez que são modos semióticos motivados.

O que tem de ver a Revisão de Texto com o Letramento? A revisão lida necessariamente com texto e discurso, podendo associar outras formas semióticas, como citado anteriormente. $\mathrm{O}$ gênero a ser revisado está associado a diferentes domínios sociais e é historicamente situado. O material a ser revisado são eventos de Letramento, produtos de práticas sociais. Cada prática representa estruturas de poder de uma sociedade. Não se procura aqui a prática de Revisão de Texto clássica apenas grafocêntrica, preocupada com mancha gráfica. E sim uma prática de Revisão que tenha consciência de que seu trabalho tem efeitos sociais em múltiplas instâncias.

\subsection{A revisão}

A revisão é uma prática antiga. A pessoa encarregada dessa tarefa é chamada de revisor de texto, cujo papel é verificar se há erros de ortografia, se o texto está corretamente direcionado aos fatos citados, dentre outros. O revisor exerce uma função essencial em empresas jornalísticas, editoras, gráficas etc. nas quais a revisão é parte do processo de elaboração do produto final (jornal, revista ou livro). No entanto, muitas empresas jornalísticas reduziram ou mesmo eliminaram as equipes de revisores após a introdução da informática nas redações. Como diz Paulo Vilhena, que há mais de 15 anos trabalha com revisão de texto "Todo texto deve ser submetido a diversas fases de revisão; as primeiras e a última pelo próprio autor, mas outras pessoas devem revisar o trabalho para que os diversos tipos de problemas sejam reduzidos ao mínimo" (VERSÃO, 2007).

$\mathrm{O}$ autor, devido à sua familiaridade com o assunto e proximidade ao texto, quase sempre comete lapsos e equívocos que ele próprio não identifica em sucessivas leituras de seu trabalho. Mesmo os orientadores acadêmicos, formalmente responsáveis pelo acompanhamento da produção, pelos mesmos motivos, estão sujeitos a tais enganos e lapsos. Os revisores profissionais trabalham melhor se o texto lhes for entregue "pronto", inteiro, de forma que depois de revisado não sofra mais mo- 
dificações. A última fase será a conferência por parte do autor das interferências do revisor, para verificar se suas intenções e ideias foram corretamente interpretadas.

Em muitos casos, o revisor pode mesmo tornar-se num coautor do texto, a partir da proposta de melhorar a argumentação quando for necessário. Isso é frequente, por exemplo, no âmbito jornalístico e, em alguns países, no contexto literário, podendo este revisor, por exemplo, chegar a ponto de alterar o final de um romance ou seu título.

A problemática que envolve a prática da Revisão de Texto gira em torno das técnicas que devem ser utilizadas para que o revisor faça bem o seu trabalho, e o produtor acabe satisfeito. A partir disso, então, poder-se-ia afirmar que um bom revisor deve considerar as correções ortográfica e gramatical, procurar dar clareza às ideias, levando em conta elementos como coerência e coesão e, principalmente, não deixar que suas alterações interfiram no sentido que o produtor deu ao texto. O trabalho do revisor é, portanto, garantir que o texto fique claro, e a ideia do autor seja transmitida da melhor forma possível. Esse é o ponto de vista da Revisão clássica. Mas ainda não é só isso, como veremos a seguir.

Pelo fato de que a Revisão de Texto vai muito além de um trabalho técnico e além dos pressupostos do autor citado anteriormente, ou da aplicação das regras gramaticais, é preciso que haja, entre produtor e revisor, a negociação do sentido, em que ambos possam chegar a um ponto em comum em relação às intenções do texto.

Voltemos à pergunta inicial, respondendo, preliminarmente, a segunda questão de pesquisa. Digo "preliminarmente" porque, durante o desenvolvimento deste trabalho, o tópico será mais aprofundado. A Revisão de Texto, dentro de suas atividades, pode ser associada às teorias críticas? Vejamos.

\subsection{Revisão e ADC}

Na Análise de Discurso Crítica, a revisão é uma prática eminentemente social. De outra parte, o quadro tridimensional pode ser aplicado a ela, pois analisa 
estruturas microtextuais (prática de texto - estruturas linguísticas); e, por consequência, esses elementos estão inseridos a um gênero discursivo (prática discursiva - propaganda de TV, outdoor, tese etc.); e, consciente ou inconscientemente, este gênero está inserido em questões de poder (práticas sociais - como pessoas, instituições, agem sobre as outras pessoas ou sobre o mundo). Veja-se, a seguir, o quadro tridimensional, associado à Revisão de Texto:

Revisão de Texto associada ao Quadro Tridimensional do Discurso

\section{Prática Social}

Instituições ideologicamente constituídas:

- Serviço público (Executivo, Legislativo e Judiciário); empresas jornalísticas; gráficas, academias etc.

\section{Prática Discursiva}

\section{Eventos discursivos:}

- Folders, cartazes, periódicos, dissertações, teses, monografias, e-mails, manuais.

\section{Texto \\ Aspectos formais}

- Pontuação, acentuação, hífen, inicias maiúsculas, sintaxe de regência, concordância, colocação, ordenação sintática, coesão, palavras.

\subsection{Revisão de texto e a multimodalidade}

Considerar a prática de Revisão de Texto um processo simplesmente mecânico é um pensamento errôneo. Sabe-se que um texto envolve muito mais do que as regras gramaticais; ele engloba contextos: subjetivos, sociais, históricos, linguísticos e cognitivos. Isso porque na construção de um texto, existem tantos elemen- 


\subsubsection{Gênero híbrido}

Antes de passarmos à análise, precisamos de alguns conceitos básicos em Linguística. O gênero em foco é constituído de vários modos semióticos, o que o torna uma produção híbrida. Mas o que é um gênero discursivo híbrido? Entende-se por gênero híbrido aquele que incorpora vários modos semióticos, que concorrem para a sua constituição. Lida com intertextualidade, relaciona cores, estruturas linguísticas, texto; formatação; posição de elementos na composição etc. O texto híbrido surge na contemporaneidade, para transpor a ideia de que uma imagem é dissociada do texto. $\mathrm{O}$ gênero propaganda nos mostra isso claramente, pois se utiliza dos muitos modos semióticos para alcançar seus "leitores” e propagar suas ideias. É o que veremos na subseção a seguir.

Em um contexto escolar, poderíamos aplicar o gênero acima e pedir para que os alunos o analisassem e o revisassem. Não importa que a peça discursiva apresente ou não impropriedades passíveis de adequações linguística, contextual, genérica ou visual. $\mathrm{O}$ mais importante é o contato dos discentes com um gênero e o desvelamento de seus múltiplos sentidos.

\subsubsection{Análise/interpretação}

A imagem utilizada nos remete à história de Chapeuzinho Vermelho que, na referida história, vai por um bosque visitar a avó e é quase engolida pelo Lobo Mau. A imagem foi utilizada pelo Greenpeace para a sensibilização nas questões de problemas ambientais, como o desmatamento. Mas quais foram os mecanismos utilizados para atingirem seus propósitos?

A peça discursiva reúne as tradições analíticas: a tradição da análise textual (microtextual); a tradição macrossociológica de análise na prática social e da prática discursiva. Em termos de prática social, o gênero foi produzido ativamente para atingir finalidade(s), desse modo invocou uma série de modos semióticos motivados para atingir seus objetivos - categorias microtextuais (estruturas linguísticas), modos visuais (imagens, disposição de imagem, cores). Como afirmam Kress, Leite-Garcia e Van Leeuwen (2000), o interesse de um produtor de um signo o conduz a uma rela- 
tos envolvidos quanto é a complexidade deles. Porém, pode-se dizer que sem um desses elementos, em especial, não há como se ter, sequer, uma frase. Seja qual for o tema, seja qual for a intenção ao se produzir um texto, ele vai ser consequência do ponto de vista, do contexto, do sentido, enfim dos conhecimentos de seu produtor, e tudo isso faz parte de uma construção.

Em que ponto se pode afirmar que a Revisão de Texto é uma prática multimodal? Responderemos nas próximas subseções.

\subsection{Da teoria à prática}

Nesta seção, trataremos da Revisão de Texto como uma forma de multiletramento. Vimos até agora que a Multimodalidade e o Letramento, embasados na Análise de Discurso Crítica, podem nos trazer uma nova concepção de análise de texto e de ensino. Podemos, respaldados pelos vários modos semióticos, ter novos olhares a respeito do mundo via gêneros que revisamos todos os dias.

Esta parte do trabalho tem como objetivo principal trazer à prática os pressupostos discutidos em seção anterior - qual seja, associar as teorias críticas à Revisão na prática.

"Leiam" a imagem a seguir:

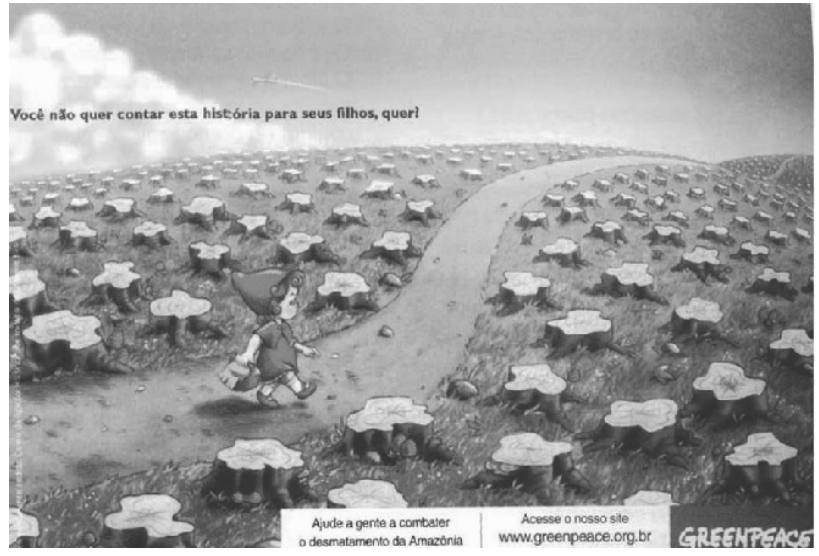


ção motivada entre significado e significante. Por essa razão, os semioticistas críticos enfatizam a estruturação sistemática da imagem em uma sintaxe visual.

A coerência (a ancoragem do significado) da mensagem é relativa - pode fazer sentido para um grupo, para outros não, para um contexto, para outro não. Em termos de prática social, o Greenpeace tem uma constituição ideológica bastante acentuada, o que entra em confronto com interesses de empresas de fazendeiros, que lucram com desmatamento. Nessa relação, materializa-se uma prática social conflitante, uma ideologia historicamente materializada (materialismo histórico) passível de análise em um gênero. A coerência, o fazer sentido de uma peça discursiva, depende em muito de como os modos semióticos foram organizados como redutores de ambivalência - deve fazer sentido, ser interpretado, pela maioria dos viewers. Tudo depende do design do gênero. Isso nos desperta para a produção, distribuição e consumo de texto, três elementos interligados. Se o primeiro não tiver a distribuição e o consumo, não terá ação sobre as outras pessoas e sobre o mundo.

Além dos elementos arrolados anteriormente, uma categoria bastante presente é a intertextualidade implícita, isso provoca uma heterogeneidade de ordens discursivas (interdiscursividade). O gênero invoca formações discursivas várias: o Greenpeace lança mão do discurso de uma história infantil, do discurso do desmatamento e de seu próprio discurso. Veja-se que a natureza está bastante mudada, mas Chapeuzinho Vermelho continua pura, ingênua, com a mesma aparência. Esse jogo de formações discursivas suscita uma antítese - a pureza (na história de Chapeuzinho havia uma floresta intocada, onde o lobo poderia esconder-se, e uma certa nostalgia do passado do Greenpeace quando nossas matas eram intocadas) e a realidade crua do desmatamento em que o lobo não pode se esconder mais em florestas, porque estas não existem mais, mas o fazem em aviões aplicando agrotóxicos ou em escritórios.

Percebemos claramente que não há árvores nesse bosque, melhor dizendo havia, mas foram recentemente cortadas, pois, se formos analisar melhor os troncos, não parecem estar ali há muito tempo cortados.

Ao analisarmos, também podemos perceber um avião que corta o céu no alto da imagem, despejando agrotóxicos. Isso representa o contraste moderno/ma- 
gia, fantasia/realidade. O uso de uma imagem focada no público infantil é para enfatizar que, mesmo sendo uma imagem naturalizada no universo infantil, pode ser quebrada, o encanto pode acabar - a realidade do desmatamento. Urge que os pais continuem contando a história de Chapeuzinho, mantendo a fantasia, ou seja, conservando a natureza.

Sobre as categorias microtextuais nos usos dos imperativos: "Você não quer contar essa história para seus filhos, quer?” “... ajude, acesse, fique sócio...”. O emprego do imperativo de natureza linguística é típico de propaganda que se caracteriza pela tipologia textual injuntiva - visa influenciar o receptor sobre alguma questão e mudar seu comportamento para agir, consumir. A palavra história está escrita com $h$ justamente para dizer que não se está falando de coisas que acontecem no mundo da imaginação, mas sim para demonstrar que se nossas ações como seres humanos, responsáveis pelos bens naturais, não mudarem, nossos filhos, nossas futuras gerações sofrerão. A expressão "Você não quer contar esta história pra seus filhos, quer?", o questionamento é meramente retórico. Já sabemos a resposta. Urge que se mantenha a "fantasia" das histórias infantis.

O uso de um desenho ao invés da fotografia foi feito em virtude dos objetivos da propaganda, chocar e sensibilizar. Se fosse utilizada uma fotografia, perder-se-ia muito nas intenções. O desenho tem uma característica infantil, tem o tom do sonho, da fantasia, e os elementos, por exemplo, a estrada por onde Chapeuzinho passava e o avião entram neste gênero para mostrar que até lá, no sonho, a maldade humana já conseguiu tocar.

Na perspectiva da Multimodalidade, vê-se, no gênero analisado, uma representação visual marcante em detrimento de categorias linguísticas. Isso permite a realização do sentido de muitas maneiras em diferentes níveis, em diferentes articulações. As quatro categorias em que os sentidos são realizados:

- O discurso - na ideologia e finalidade do Greenpeace;

- Design - a maneira que Greenpeace realiza seu discurso em um contexto de desmatamento; 
- Produção - o Greenpeace emprega uma articulação complexa na materialidade semióticas; cada modalidade tem sua potencialidade de uso e de significação;

- Distribuição - reprodução do gênero propaganda em eventos semióticos; divulgação na mídia, consumo em larga escala; quanto mais é consumido, maior possibilidade de mudança, de ação social.

\section{Considerações}

Todas essas análises podem ser feitas nessa e em muitas outras imagens que podemos encontrar nos mais diversos lugares, livros didáticos, revistas e jornais. Uma vez que o profissional em LP faz essa escolha, como forma de letramento, ele estará dando ao aluno muitas possibilidades de se concretizar esse processo. Estará possibilitando ao discente uma relação com o mundo em que vive, tornando, assim, o estudo de LP não uma prática estagnada e fixa, mas sim multimodal, com interfaces e, acima de tudo, respeitando as diferenças e a individualidade de cada um que participa dessa grande máquina que é o ensino brasileiro. O revisor de texto clássico faria a "revisão" desse gênero focando-se apenas em estruturas linguísticas. Deixaria de lado a riqueza visual e predominante da propaganda.

\section{Conclusão}

Fazer uma opção pela educação multimodal de LP significa negarmos qualquer compartimentação das práticas de linguagem. Significa centrar o ensino nas práticas de leitura de textos, de produção de textos e de análise linguística e de aspectos multissemióticos, aí incluído o estudo da gramática. Tais práticas, se tomadas de maneira estanque, não se justificam, uma vez que a gramática da língua deve permear as atividades de leitura e de produção de textos, e estas, por sua vez, necessitam de um suporte gramatical mesmo que não explicitado.

Segundo Geraldi (1996), a prática de análise linguística se dá concomitantemente à leitura, quando esta deixa de ser mecânica para se tornar construção de uma compreensão dos sentidos veiculados pelo texto, e à produção de textos, 
quando esta perde seu caráter artificial de mera tarefa escolar para se tornar momento de expressão da subjetividade de seu autor, satisfazendo necessidade de comunicação a distância ou registrando para outrem e para si próprio suas vivências e compreensões do mundo de que participa.

As práticas de leitura e de produção de textos, inseridas em uma educação baseada na multimodalidade, deixam de se constituir em atividades esporádicas com a língua e assumem uma posição de destaque, por contribuírem para a formação do sujeito do discurso que é ao mesmo tempo falante-ouvinte-leitor-escritor.

A educação multimodal alicerçada na concepção de letramento pretende ultrapassar o domínio da leitura e da escrita como mera capacidade de decodificação e codificação de signos. Não ignoramos, porém, que tal capacidade é condição sine qua non para os processos de interpretação, análise, crítica e inferência.

O educador precisa ter clareza que o ensino essencialmente gramatical contribui para a construção de uma falsa ideia da língua. Definidas as reais concepções de linguagem e de língua, novas tarefas se impõem. A mais importante é favorecer uma nova identidade linguística aos alunos, a de "poliglotas" de sua própria língua (BECHARA, 2000, p. 58).

Para que todos esses objetivos sejam alcançados de forma eficaz, é necessário que a escola se abra para novas possibilidades. É importante que o atual conceito de Letramento seja revisto, que o uso e a importância que se dá ao uso da GT em sala de aula sejam reavaliados. Por meio da Análise de Discurso Crítica, cada instituição de ensino poderá reescrever sua própria história nos caminhos do Letramento. Se cada uma dessas instituições entender e assimilar como a Revisão de Texto, sob uma perspectiva multimodal, pode fazer a diferença no ensino de LP, com certeza, teremos, não em alguns anos, não para que nós vejamos, mas para que nossos filhos e netos possam desfrutar de um ensino de LP muito mais atrativo, pois essas novas possibilidades permitem um ensino não embasado em manuais e regras que destacam e excluem grupos, mas um ensino rico de sociedade, vivência e valores. 
Percebemos que com a análise da imagem, podemos ampliar esse ensino de LP de forma considerável a partir do momento em que mais análises forem feitas dentro do material utilizado na rede de ensino. Entendemos que o Letramento pode tomar uma proporção muito maior dentro do âmbito escolar, no momento em que sua concepção for ampliada, no momento em que a GT deixar de ser o principal recurso do ensino de LP. Vivemos um ensino fracassado e cheio de rusgas, isso porque os “atores” deste grande filme há muito não se preocupam em lutar por uma ideia de outro final, um final feliz.

\section{The multimodality of revision of the text: a way to literacy}

\section{Abstract}

The written language is becoming, increasingly, only one of many modes of representation in the public domain. A Critical Discourse Analysis (CDA) is up from the perception of discourse as an element of social practices with a dialectic view between language and society. Thus, this theory considers the discourse as an integration of various forms of semiotic modes, where the speakers, to make use of languages available, acting on other people and the world. On the other hand, the communication has always been multissemiotic, but take that approach becomes something new and frightening, especially for grafocentrics societies. The scenario changes in communication have remained outside the teaching of Portuguese Language in Brazil because, in large part, values, although the autonomous model of Literacy, focusing on understanding the nomenclature grammar in activities fossilized, non-significant and outside the social context of pupils and students. Our view is justified because we must keep up with changes and prepare for future teachers to the activities of broader language, bringing social practices, the events discourse and practice of text to the classroom. My project's theoretical foundation Barton (1994); Hamilton \& Ivanic (2000); Street (1993), Fairclough (2003), Chouliaraki \& Fairclough (1999), Kress e Van Leeuwen (1996).

Keywords: Teaching portuguese language. Revision of text. Critical discourse analysis. literacy. 


\section{Referências}

BAGNO, Marcos. Português ou brasileiro? um convite à pesquisa. São Paulo: Parábola, 2001.

BAKHTIN, M. Estética da criação verbal. Tradução de Maria Galvão Gomes Pereira. São Paulo: M. Fontes, 1997.

BARTON, D. Literacy: an introduction to ecology of written language. London: Blackwell, 1994.

BECHARA, Evanildo. Moderna gramática portuguesa. Rio de Janeiro: Lucerna, 2000.

BRASIL. Ministério da Educação. Parâmetros Curriculares Nacionais (PCN). Salvador: Governo da Bahia, 2000.

CHAFE, Wallace. Discourse and social change. Cambridge: Polity Press, 1992.

CHAFE, W. Integration and Involvement in Speaking, Writing and Oral Literature. In: TANNEN, D. (org.). Spoken and written language: exploring orality and literacy. New Jersey: Norwwod, 1982.

CHOULIARAKI, Lilie; FAIRCLOUGH, Norman. Discourse in late modernity: rethinking critical discourse analysis. Edinburgh: Edinburgh University Press, 1999.

FAIRCLOUGH, Norman. Analysing discourse: textual analysis for social research. London; New York: Routledge, 2003.

FLICK, Uwe. Uma introdução à pesquisa qualitativa. São Paulo: Bookman, 2004.

GERALDI, João W. Linguagem e ensino: exercícios de militância e divulgação. Campinas: Mercado de Letras, 1996.

HAMILTON, Mary. Local literacies: reading and writing in one community.

London: Routledge, 1998.

HAMILTON, Mary; IVANIC, R. Situated literacies. London: Routledge, 2000.

HAMILTON, M [et al]. Worlds of literacy. Clevedon: Multilingual Matters Ltda., 1998 
HODGE, Robert; KRESS, Gunther. Social semotics. Cambridge: Polity Press, 1988.

KLEIMAN, Ângela B. (Org.). Os significados do letramento: uma nova perspectiva sobre a prática social da escrita. Campinas: Mercado de Letras, 1995.

KRESS, Gunther. Multimodal texts and critical discourse analysis. In: PEDRO, E. (Org.). Discourse analysis: proceedings of the First International Conference on Discourse Analysis. Lisbon: University of Lisbon, 1996.

KRESS, Gunther; LEITE-GARCIA, R.; VAN LEEUWEN, Theo. Semiótica discursiva. In: VAN DIJK, Teun A. (Comp.) El discurso como estructura y processo estudios sobre el discurso: una introducción multidisciplinaria.. Espanha: Gedisa, 2000. p. 335-372.

KRESS, Gunther; VAN LEEUWEN, Theo. Multimodal discourse: the modes and media contemporary communication. New York: Oxford, 2001.

KRESS, Gunther; VAN LEEUWEN, Theo. Reading images: the grammar of visual design. London: Routledge, 1996.

MARCUSCHI, Luiz A. Gêneros textuais: definição e funcionalidade. In: DIONÍSIO, Ângela P. et al. (Org.). Gêneros textuais \& ensino. Rio de Janeiro: Lucerna, 2002.

STREET, B. Cross-cultural approaches to literacy. Cambridge: Cambridge University Press, 1993.

STREET, B. Literacy in theory and practice. Cambridge: Cambridge University Press, 1984.

VERSÃO integral. Revisão profissional de textos. Disponível em: < http://www. revisaodetexto.com.br/>. Acesso em: 2007.

VIEIRA, Josenia A.; SILVA, Denise Elena G. Práticas de análise de discurso. Brasília: Plano, 2003. 